\title{
PARK7-Related Early Onset Parkinson Disease in the Setting of Complete Uniparental Isodisomy of Chromosome 1
} Changrui Xiao, MD, Thomas Markello, MD, Wadih M. Zein, MD, Rachel Bishop, MD, Catherine Groden, APN,
William Gahl, MD, and Camilo Toro, MD

Neurol Genet 2021;7:e606. doi:10.1212/NXG.0000000000000606

Approximately $10 \%$ of Parkinson disease (PD) has a monogenic basis. PARK7 is a rare recessive form of early-onset PD caused by mutations in the gene PARK7 (formerly DJ1). ${ }^{1}$ As expected for a recessive disorder, PARK7 patients usually inherit 1 mutant allele from each parent; in fact, most reported cases have occurred in consanguineous families. We report an adult with early onset $\mathrm{PD}$ who inherited 2 identical pathogenic $P A R K 7$ variants from her asymptomatic father, a carrier for the same variant, via complete uniparental isodisomy (UPD) of chromosome 1.

UPD occurs when an offspring inherits 2 copies of a chromosome or segments of a chromosome from 1 parent and none from the other. In UPD, the abnormally inherited chromatin segments are identical. UPD can result from meiotic nondisjunction when an abnormal gamete forms either a monosomic or trisomic zygote followed by either duplication of the monosomic chromosome (monosomy rescue) or loss of the trisomic chromosome (trisomy rescue). ${ }^{2}$ Mechanisms of disease in the context of UPD include overexpression or underexpression of imprinted genes or, because in this case, emergence of homozygosity for pathogenic variants contributed by the segments of chromatin involved. Advanced maternal age is the only established risk factor for UPD.

\section{Case}

A 38-year-old woman was referred to the NIH Undiagnosed Diseases Program after seeking medical attention for progressive dysphonia since age 31 . Her examination was notable for hypophonia, masked facies, bradykinesia, asymmetric upper extremity rigidity, micrographia, and resting tremor consistent with parkinsonism. She had brisk reflexes throughout with no other pyramidal features. She had a history of depression treated with antidepressants, although at the time of psychiatry evaluation she did not meet criteria for any psychiatric diagnosis. She endorsed mild subjective forgetfulness, inattentiveness, and apathy with previously unremarkable neurocognitive testing. She did not endorse olfactory changes or constipation. An overnight polysomnogram demonstrated severe obstructive sleep apnea without signs of parasomnias. Trials of levodopa/carbidopa and pramipexole improved symptoms but were poorly tolerated because of gastrointestinal side effects. MRI (Figure 1) and EMG were normal. Her parents were unrelated, and there was no family history of PD.

Her history was also notable for progressive vision loss in her twenties. Ophthalmologic evaluation uncovered changes consistent with Stargardt macular dystrophy (eFigure 1, links. lww.com/NXG/A438) as well as mild cataracts. Birth and developmental history were within normal limits. Her physical examination was also notable for joint hypermobility (Beighton

\author{
Correspondence \\ Dr. Xiao \\ changrui.xiao@nih.gov
}


A

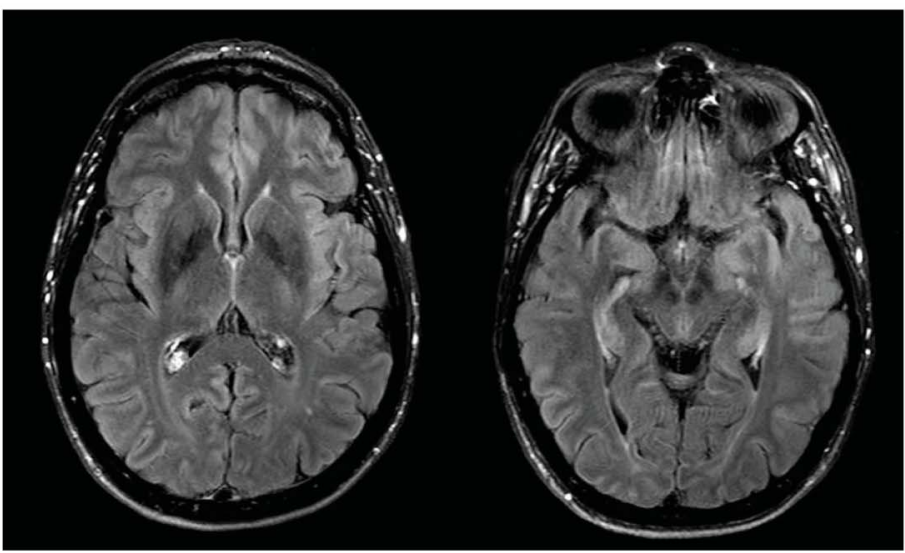

C

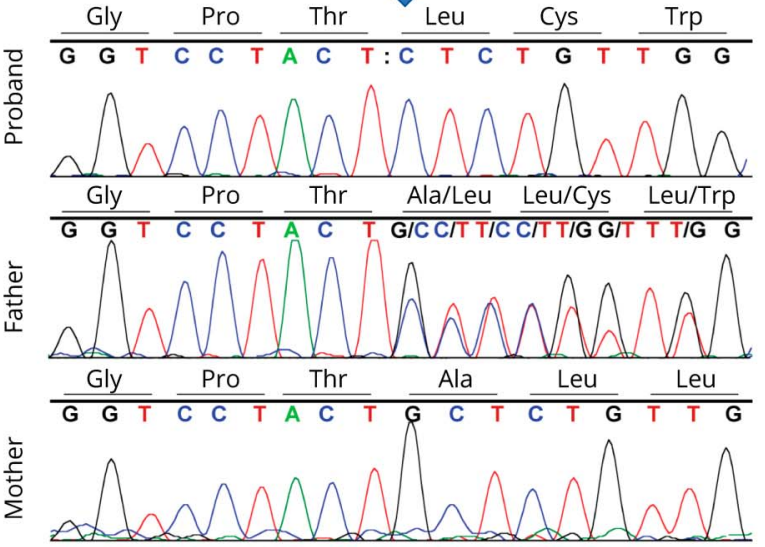

B
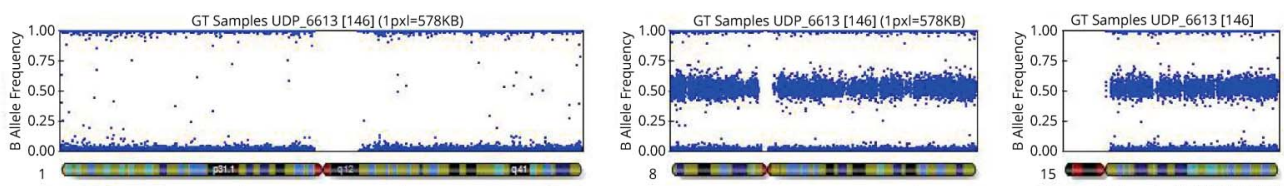

1.00 GT Samples UDP $6613[146](1 \mathrm{px})=579 \mathrm{~KB})$

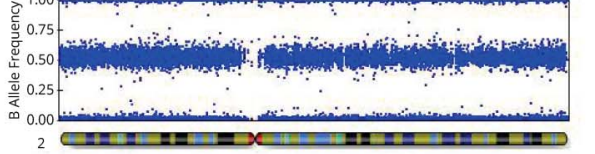

1.00 GT Samples UDP_6613 [146] (1pxl=579KB)

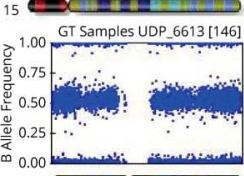

GT Samples UDP_6613 [146] (1pxl=579KB)
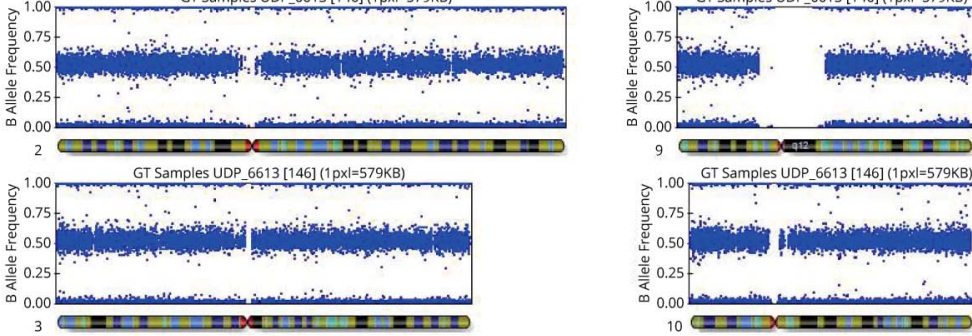

GT Samples UDP_6613 [146] (1px|=579KB)

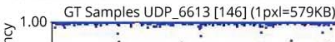

$\overbrace{}^{1.00}$

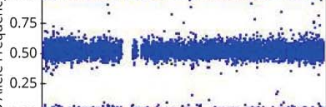

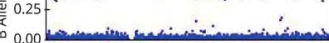

$10=x=1=2=1$

1.00 GT Samples UDP $6613[146]$ (1 pxl=579KB)

1.00 GT Samples UDP 6613 [146] (1 pxl=579KB)

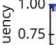

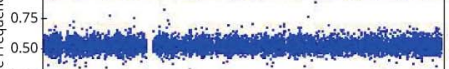

空 0.50

离 0.25

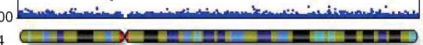

100 GT Samples UDP_6613 [1 46] (1 pxl=580KB)

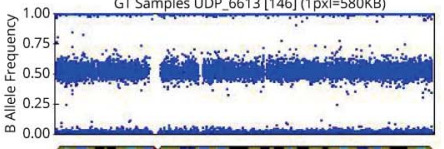

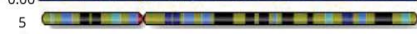

1.00 GT Samples UDP_6613 [146] (1px|=580kB)

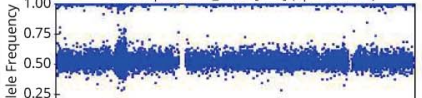

状

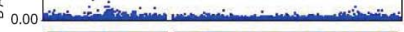

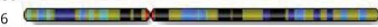

1.00 GT Samples UDP.6613 [146] (1px)=579KB)
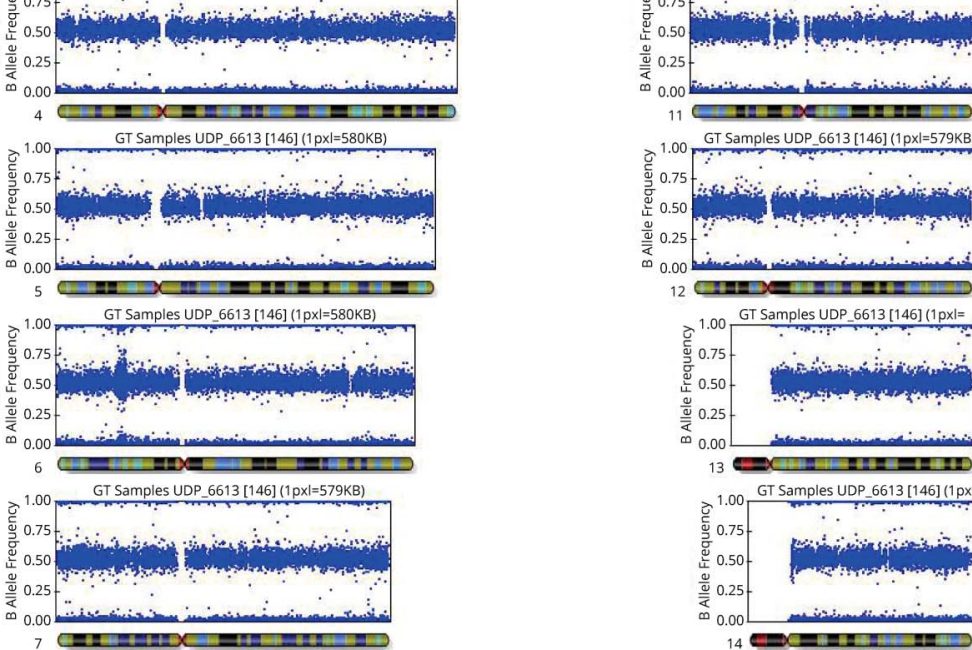

$\stackrel{0}{0} 0.25$
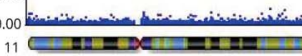

O 1.00 GT Samples UDP_6613 [146] (1px)=579KB

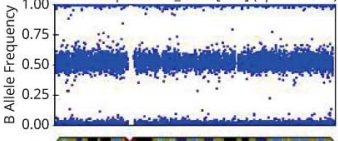

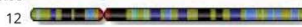

1.00 GT Samples UDP_6613 [146] (1px)=

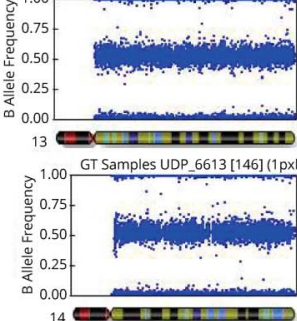

$16 \Longrightarrow$ 921 =

1.00 GT Samples UDP_6613

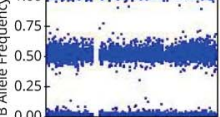

1700

1.00 GT Samples UDP 6613

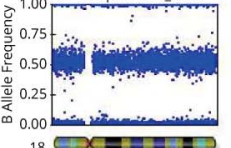

$22=0$
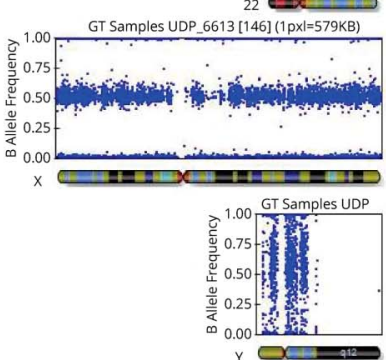

(A) MRI fluid-attenuated inversion recovery shows normal striatum (left) and midbrain (right). (B) Single nucleotide polymorphism microarray (SNP array) data for all chromosomes show loss of heterozygosity in chromosome 1 in an otherwise normal background. (C) Sanger sequencing confirmed deletion in the proband, heterozygosity in father, and no deletion in the mother.

score 6/9), scoliosis, micrognathia, elevated palate, pectus excavatum, and mild sensorineural hearing loss.

A nuclear family single nucleotide polymorphism (SNP) microarray study identified complete UPD of the entire chromosome 1 (Figure 1). Genome sequencing revealed a homozygous truncating PARK7 mutation (c.331delG, p.A111LfsX7) of paternal origin as well as homozygosity for a previously reported ABCA4 variant (c.1805 G > A, p.R406Q). Both variants were validated by Sanger sequencing and interpreted 
as pathogenic by American College of Medical Genetics criteria. The proband's father, but not her mother, was heterozygous for both variants (Figure 1).

\section{Discussion}

Early-onset PD due to PARK7 is rare. A comprehensive review of the literature in 2018 identified 30 cases in 18 families, with most cases involving homozygous mutations. ${ }^{3}$ The mechanism by which PARK7 mutations lead to parkinsonism is unclear; $P A R K 7$ is thought to play roles as a chaperone with protease activity, a mitochondrial stabilizer, a reduction-oxidation sensor, a transcriptional regulator, and an oncogenic agent. ${ }^{4}$ The incidence of PARK7 remains unknown, although it is estimated to account for less than 1 percent of patients with early onset of PD in the United States. ${ }^{3}$ Both missense mutations and truncating mutations have been reported, with studies demonstrating functionally inactive or complete lack of DJ1 expression. ${ }^{5}$ Our patient's variant has not been previously reported, and this is the report of PARK7 early onset PD emerging from UPD.

Our patient's phenotype additionally includes macular dystrophy, hearing loss, micrognathia, scoliosis, and pectus excavatum. The same mechanism leading to homozygosity in $P A R K 7$ also led to homozygosity for a pathogenic variant in $A B C A 4$, supporting a diagnosis of Stargardt macular dystrophy. ${ }^{6}$ While our evaluation did not identity definite explanations for her remaining findings, homozygous variants of unclear significance were identified in short stature genes on chromosome 1 .

The incidence of UPD in the general population is estimated at 1 : 2,500, and most individuals with UPD in nonimprinted chromosomes are phenotypically normal. ${ }^{7}$ The likelihood of unmasking a given recessive condition by UPD is contingent on the joint probability of a particular UPD event and the carrier frequency for disease-causing variants in the implicated gene.

Disease-specific gene panel testing for PD or macular dystrophy would have identified homozygous PARK7 or ABCA4 changes. However, to provide full account of the phenotype and fully understand the inheritance mechanism, parental segregation, chromosomal microarray, or genomic sequencing would have been required to provide a unified explanation for her complex presentation. Considering UPD and its potential systemic implications is relevant even in specialty clinics, particularly when encountering rare recessive homozygous mutations in the absence of consanguinity or when complex phenotypes and rare genetic diagnoses aggregate in 1 individual.

\section{Acknowledgment}

The authors wish to thank patients, families, consultants, and referring physicians participating in the NIH Undiagnosed Diseases Program.

\section{Study Funding}

The NIH Undiagnosed Diseases Program is funded by the NIH Common Fund, NIH, Bethesda MD, USA.

\section{Disclosure}

The authors report no disclosures relevant to the manuscript. Go to Neurology.org/NG for full disclosures.

\section{Publication History}

Received by Neurology: Genetics February 12, 2021. Accepted in final form May 13, 2021.

Appendix Authors

\begin{tabular}{lll}
\hline Name & Location & Contribution \\
\hline $\begin{array}{ll}\text { Changrui } \\
\text { Xiao, MD }\end{array}$ & $\begin{array}{l}\text { National Human Genome } \\
\text { Research Institute, Bethesda, } \\
\text { MD }\end{array}$ & $\begin{array}{l}\text { Drafting/revision of the article } \\
\text { for content, including medical } \\
\text { writing for content; major role } \\
\text { in the acquisition of data; and } \\
\text { analysis or interpretation of } \\
\text { data }\end{array}$ \\
& \\
\end{tabular}

Thomas Office of the Clinical Director, Drafting/revision of the

Markello, National Human Genome article for content, including

MD Research Institute, Bethesda, $\mathrm{MD}$

medical writing for content, and major role in the acquisition of data

\begin{tabular}{|c|c|c|}
\hline $\begin{array}{l}\text { Wadih M. } \\
\text { Zein, MD }\end{array}$ & $\begin{array}{l}\text { National Eye Institute, } \\
\text { Bethesda, MD }\end{array}$ & $\begin{array}{l}\text { Major role in the acquisition of } \\
\text { data and analysis or } \\
\text { interpretation of data }\end{array}$ \\
\hline $\begin{array}{l}\text { Rachel } \\
\text { Bishop, } \\
\text { MD }\end{array}$ & $\begin{array}{l}\text { National Eye Institute, } \\
\text { Bethesda, MD }\end{array}$ & $\begin{array}{l}\text { Major role in the acquisition of } \\
\text { data }\end{array}$ \\
\hline $\begin{array}{l}\text { Catherine } \\
\text { Groden, } \\
\text { APN }\end{array}$ & $\begin{array}{l}\text { NIH Undiagnosed Diseases } \\
\text { Program, National Human } \\
\text { Genome Research Institute, } \\
\text { Bethesda, MD }\end{array}$ & $\begin{array}{l}\text { Major role in the acquisition of } \\
\text { data }\end{array}$ \\
\hline $\begin{array}{l}\text { William } \\
\text { Gahl, MD }\end{array}$ & $\begin{array}{l}\text { NIH Undiagnosed Diseases } \\
\text { Program, National Human } \\
\text { Genome Research Institute, } \\
\text { Bethesda, MD }\end{array}$ & $\begin{array}{l}\text { Drafting/revision of the article } \\
\text { for content, including medical } \\
\text { writing for content; major role } \\
\text { in the acquisition of data; and } \\
\text { study concept or design }\end{array}$ \\
\hline $\begin{array}{l}\text { Camilo } \\
\text { Toro, MD }\end{array}$ & $\begin{array}{l}\text { NIH Undiagnosed Diseases } \\
\text { Program, National Human } \\
\text { Genome Research Institute, } \\
\text { Bethesda, MD }\end{array}$ & $\begin{array}{l}\text { Drafting/revision of the article } \\
\text { for content, including medical } \\
\text { writing for content; major role } \\
\text { in the acquisition of data; study } \\
\text { concept or design; and analysis } \\
\text { or interpretation of data }\end{array}$ \\
\hline
\end{tabular}

\section{References}

1. Cook Shukla L, Schulze J, Farlow J, Pankratz ND, Wojcieszek J, Foroud T. Parkinson disease overview. In: Adam MP, Ardinger HH, Pagon RA, et al, eds. GeneReviews [online]. University of Washington, Seattle; 1993. Accessed January 17, 2020, ncbi. nlm.nih.gov/books/NBK1223/.

2. Robinson WP. Mechanisms leading to uniparental disomy and their clinical consequences. Bioessays. 2000;22(5):452-459.

3. Kasten M, Hartmann C, Hampf J, et al. Genotype-phenotype relations for the Parkinson's disease genes parkin, PINK1, DJ1: MDSGene systematic review. Mov Disord. 2018;33(5):730-741.

4. Ottolini D, Calì T, Negro A, Brini M. The Parkinson disease-related protein DJ-1 counteracts mitochondrial impairment induced by the tumour suppressor protein $\mathrm{p} 53$ by enhancing endoplasmic reticulum-mitochondria tethering. Hum Mol Genet Oxford Acad. 2013;22(11):2152-2168.

5. Bonifati V, Rizzu P, van Baren MJ, et al. Mutations in the DJ-1 gene associated with autosomal recessive early-onset parkinsonism. Science. 2003;299(5604): 256-259.

6. Briggs CE, Rucinski D, Rosenfeld PJ, Hirose T, Berson EL, Dryja TP. Mutations in ABCR (ABCA4) in patients with sargardt macular degeneration or cone-rod degeneration. Invest Ophthalmol Vis Sci. 2001;42(10):2229-2236.

7. Nakka P, Pattillo Smith S, O'Donnell-Luria AH, et al. Characterization of prevalence and Health consequences of uniparental disomy in four million individuals from the general population. Am J Hum Genet. 2019;105(5):921-932. 


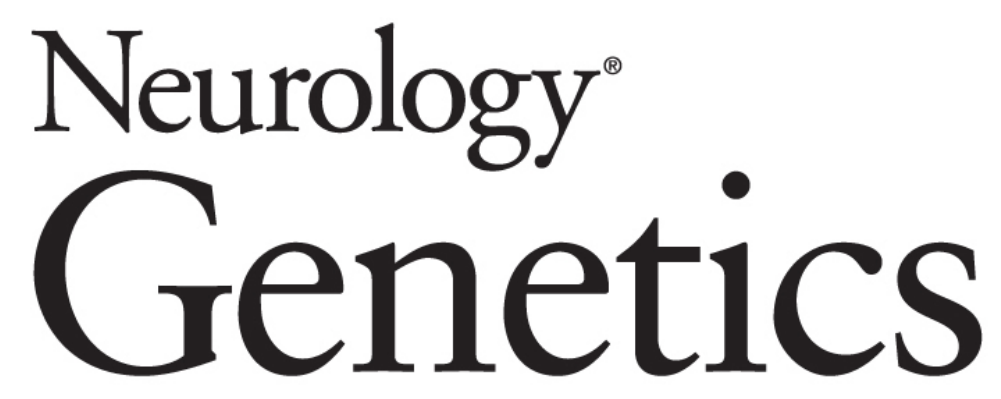

\section{PARK7-Related Early Onset Parkinson Disease in the Setting of Complete Uniparental Isodisomy of Chromosome 1 \\ Changrui Xiao, Thomas Markello, Wadih M. Zein, et al. \\ Neurol Genet 2021;7; \\ DOI 10.1212/NXG.0000000000000606}

\section{This information is current as of July 15, 2021}

\section{Updated Information \& Services}

References

Subspecialty Collections

Permissions \& Licensing

Reprints including high resolution figures, can be found at: http://ng.neurology.org/content/7/4/e606.full.html

This article cites 6 articles, 2 of which you can access for free at: http://ng.neurology.org/content/7/4/e606.full.html\#\#ref-list-1

This article, along with others on similar topics, appears in the following collection(s):

All Genetics

http://ng.neurology.org//cgi/collection/all_genetics

Parkinson's disease/Parkinsonism

http://ng.neurology.org//cgi/collection/parkinsons_disease_parkinsonis $\mathrm{m}$

Information about reproducing this article in parts (figures,tables) or in its entirety can be found online at:

http://ng.neurology.org/misc/about.xhtml\#permissions

Information about ordering reprints can be found online: http://ng.neurology.org/misc/addir.xhtml\#reprintsus

Neurol Genet is an official journal of the American Academy of Neurology. Published since April 2015, it is an open-access, online-only, continuous publication journal. Copyright Copyright $\odot 2021$ The Author(s). Published by Wolters Kluwer Health, Inc. on behalf of the American Academy of Neurology.. All rights reserved. Online ISSN: 2376-7839.

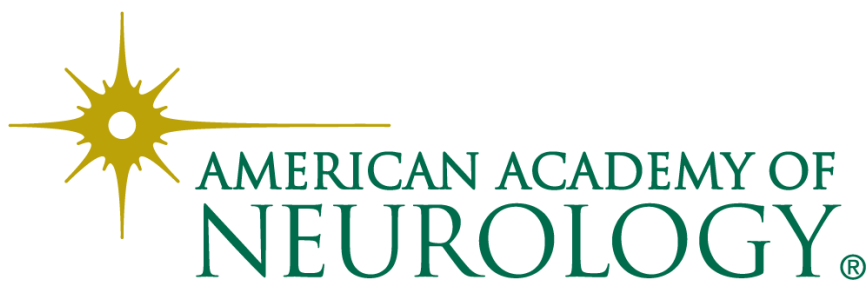

